\title{
Comparison of the inbred lines derived from a hybrid of tobacco (burley $X$ flue cured) by dihaploidy and single seed descent
}

J. L. Jinks,

M. K. U. Chowdhury and

H. S. Pooni
Department of Genetics, University of Birmingham, Birmingham B15 2TT, U.K.

Inbred lines extracted by single seed descent (129 SSD families) and by dihaploidy (60 DH families) from a cross of a flue cured (SCR) and an air cured burley (S3) variety of tobacco have been compared in a completely randomised experiment at two planting densities (normal and double) for 11 characters including yield. The basic generations (parental varieties, $F_{1}, F_{2}$ and first backcrosses, $B_{1}$ and $B_{2}$ ) were also included to provide contemporary genetical controls.

Half the characters show no difference in mean between the SSD and DH samples of inbred lines and the majority (nine out of 11) show no difference in genetical variance. For most characters there is no suggestion that the DH sample is showing the widely reported reduction in vigour relative to the SSD sample and the original parental varieties. Indeed the DH mean is the larger, implying greater vigour in more than half the cases where the DH and SSD sample means differ significantly. It is quite clear, therefore, that the relationship between the properties of the SSD and DH samples of inbred lines differs widely between characters.

Leaving aside non-genetical explanations, the means of the inbred lines and the mean of the original parental varieties (mp) are expected to differ only in the presence of non-allelic interaction whereas the means of the SSD and DH samples of lines are expected to differ only if there is a linkage disequilibrium involving these interacting genes. Within the limitations of the genetical analyses of the basic generations these expectations are borne out.

\section{INTRODUCTION}

Since the discovery of the anther culture technique in Datura innoxia (Guha and Maheshwari, 1964; $1966)$ it has been used to produce a large number of dihaploids in many species and its potential for breeding improved plant varieties is being examined in a number of economically important crops. One important question, however, remains unresolved, namely, whether the peformance of dihaploid (DH) lines is comparable with that of the inbred lines produced by conventional inbreeding.

Reduced vigour has been widely reported among DH lines of flue-cured tobacco derived from inbred varieties and $F_{1}$ crosses relative to their source material, the parents of a cross or random samples of inbred lines derived from the same $\mathrm{F}_{1}$ by more conventional means (Burk et al.,
1972; Burk and Matzinger, 1976; Arcia et al., 1978; Brown and Wernsman, 1982; Brown et al., 1983; Schnell et al., 1980). The $\mathrm{F}_{1}$ and $\mathrm{F}_{2}$ families produced by crossing DH's have been reported to show reduced vigour compared with the corresponding families produced by crossing conventionally produced inbred lines, as have also second cycle DH lines when compared with first cycle DH's (Brown et al., 1983). There have been comparable reports of reduced vigour based upon the same kinds of comparisons with burley varieties of tobacco (Collins et al., 1973; Oinuma and Yoshida, 1974; Kasperbauer et al., 1983). But with these varieties there have also been reports of no significant differences between the performance of DH's and their source material (Denton et al., 1982).

On the simpler genetical models, which assume no epistasis and no linkage disequilibrium, random 
samples of inbred lines derived from a cross by single seed descent and dihaploidy are expected to have the same phenotypic distributions about the same mean which is also the mean of the original parents of the cross (Jinks and Pooni, 1981). For this reason the observed differences between the statistics, which describe the phenotypic distributions of the two samples of inbred lines, have been attributed to non-genetical causes or to failure of the underlying assumptions of no selection during the derivation of the inbred lines and no residual heterozygosity in the conventional inbreds or in the inbred parents of the original cross (see Interpretation and Conclusions). If however, the simpler genetical models are inadequate there are conventional genetical explanations of the differences whose validity can be tested by biometrical genetical analyses of the early generations of a cross (Jinks and Pooni, 1981).

To examine further the incidence of reduced vigour in dihaploids of tobacco and to investigate its genetical or non-genetical origin we have compared random samples of inbred lines derived from a cross between a flue cured variety (SCR) and a burley variety (S3) by single seed descent and dihaploidy. Eleven characters including yield have been investigated the genetical basis of which in this cross have already been established by Coombs (1980) and the authors.

\section{MATERIALS AND METHODS}

The tobacco (Nicotiana tabacum) materials used in this investigation were derived from an original cross between two commercial inbred varieties, SCR, a German flue-cured variety which was bred from an old U.S.A. variety known as "Golden Harvest", and S3, an air-cured burley variety of Swiss origin. The seeds of both varieties were provided by Carreras Rothmans Limited in 1976. The DH lines were produced by culturing anthers from an $\mathrm{F}_{1}$ plant followed by chromosome doubling through colchicine treatment.

The design of the experiment was a single block with individual plant randomisation. Two experiments were grown at the same site in the summer of 1983 using the same material grown at two densities, normal density $(76 \mathrm{~cm}$ between rows and $30 \mathrm{~cm}$ between plants) and double density $(76 \mathrm{~cm}$ between rows and $15 \mathrm{~cm}$ between plants). At each density a total of 2076 plants were raised consisting of the basic generations (Parents, $F_{1}, F_{2}$ and first backcrosses, $B_{1}$ and $B_{2}$ ), 129 families of SSD lines (mostly $F_{8}$ but some $F_{7}$ and $F_{6}$ ) and 60 families of DH lines. The family sizes are given in table 1 . Because of losses the SSD families were reduced to 126 at both densities and the DH families to 59 at the double density only.

A total of eleven characters were scored in each experiment of which ten were scored directly on plants in the field. The characters were:

1. Height 1 (H1): Plant height in $\mathrm{cm} 44$ days after transplanting in the field.

2. Height 2 (H2): Plant height 9 weeks after transplanting.

3. Leaf Length (LL): The length of the largest leaf in $\mathrm{cm} .10$ weeks after transplanting.

4. Leaf Breadth (LB): The breadth of the same leaf across its broadest point in $\mathrm{cm}$.

5. Flowering Time (FT): the number of days from July 1 st, to the opening of the first flower.

6. Height at flowering time (HFT): the plant height in $\mathrm{cm}$ at the time of first flowering.

Table 1 The dimensions of the experiment per density

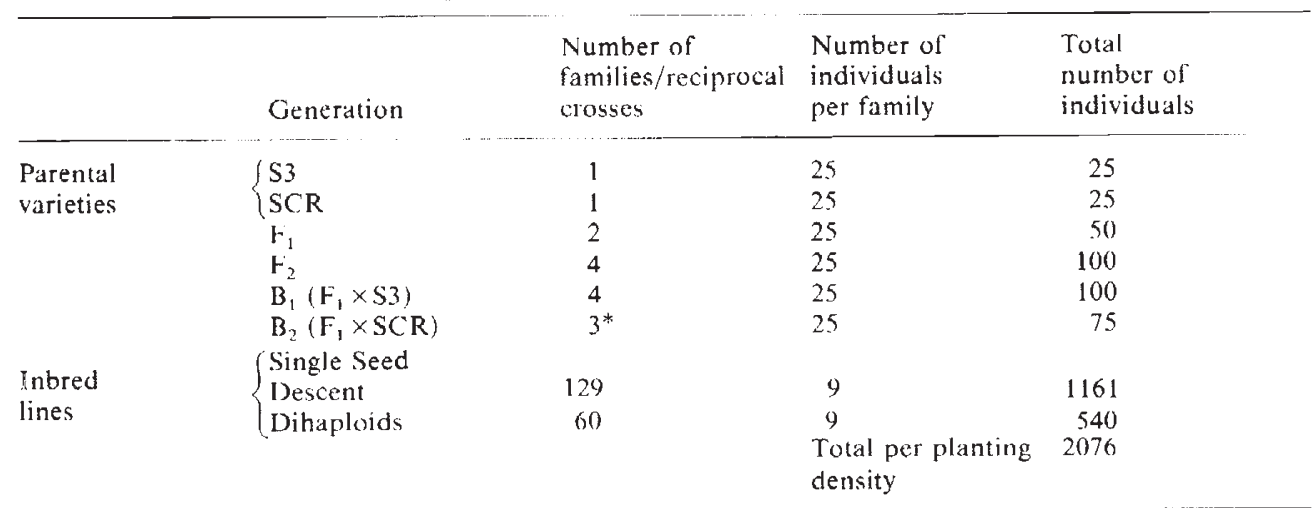

\footnotetext{
* One of the four reciprocal crosses failed
} 
7. Final height $(\mathrm{FH})$ : The height of the plant at the end of the growing season.

8. Total yield (TY): The fresh weight of the whole plant.

9. Leaf number (LN): The total number of leaf nodes from the ground to the flowering head.

10. Stem yield (SY): The weight of the stem as for total yield after removing all leaves from the plant.

11. Leaf yield (LY): Derived from 8 and 10 as total yield—stem yield.

\section{RESULTS}

The means of the SSD and DH samples of inbred lines, the mid-parent values ( $\mathrm{mp}$ ) and the results of comparing them for each character in each density are given in table 2 . There are no significant differences between the two samples of inbred lines ( $\overline{\mathrm{SSD}}-\overline{\mathrm{DH}}$ in table 2) for five of the eleven characters $(\mathrm{H} 1, \mathrm{H} 2, \mathrm{TY}, \mathrm{SY}$ and $\mathrm{LY})$ and significant differences for four (LL, LB, LN and HFT) in both densities. Flowering time (FT) shows a significant difference in the normal density only and final height $(\mathrm{FH})$ in the double density only. The DH sample has the higher mean, which for most characters implies greater vigour, for more than half the characters. Furthermore, of the ten significant differences between the SSD and DH means, the DH mean was the greater for six.

In all of the nine combinations in which the $\mathrm{mp}$ value is not significantly different from the means of the SSD and DH samples of inbred lines, these two means are also not significantly different from one a nother. Similarly, of the thirteen combinations in which the $\mathrm{mp}$ value is significantly greater (7) or smaller (6) than the means of the SSD and DH samples of inbred lines, these two means also differ significantly in ten combinations. There is, therefore, a very strong correlation between the occurrence of significant differences between the means of the SSD and DH samples of inbred lines and between these means and the mp value. This implies a common cause (see Interpretation and Conclusions).

The total variation within the SSD and DH samples of inbred lines can be partitioned into within and between family mean squares for each combination of character and density. By assuming

Table 2 The means of the SSD and DH samples of inbred lines, the mid-parental $(\mathrm{mp}$ ) values and the results of comparing them by $\mathrm{C}$ tests for eleven characters at two densities

\begin{tabular}{|c|c|c|c|c|c|c|c|c|c|c|}
\hline \multirow{2}{*}{$\begin{array}{l}\text { Character } \\
\mathrm{H} 1\end{array}$} & \multirow{2}{*}{$\begin{array}{l}\text { Density } \\
\text { ND } \\
\text { DD }\end{array}$} & \multirow{2}{*}{$\begin{array}{l}\overline{\text { SSD }} \\
14 \cdot 57 \pm 0 \cdot 49 \\
32 \cdot 28 \pm 1 \cdot 02\end{array}$} & \multirow{2}{*}{$\begin{array}{l}\overline{\mathrm{DH}} \\
14.78 \pm 0.46 \\
31.57 \pm 1.00\end{array}$} & \multirow{2}{*}{$\begin{array}{l}\mathrm{mp} \\
\begin{array}{l}11 \cdot 72 \pm 0.74 \\
32.05 \pm 2.84\end{array}\end{array}$} & \multicolumn{2}{|c|}{$\overline{\mathrm{SSD}}-\overline{\mathrm{DH}}$} & \multicolumn{2}{|c|}{$\overline{\mathrm{SSD}}-\mathrm{mp}$} & \multicolumn{2}{|c|}{$\overline{\mathrm{DH}}-\mathrm{mp}$} \\
\hline & & & & & $\begin{array}{r}-0.21 \\
0.71\end{array}$ & $\begin{array}{l}\text { NS } \\
\text { NS }\end{array}$ & $\begin{array}{l}2 \cdot 85 \\
0 \cdot 23\end{array}$ & $\stackrel{+}{\text { NS }}$ & $\begin{array}{r}3 \cdot 06 \\
-0.46\end{array}$ & $\stackrel{+}{+}$ \\
\hline $\mathrm{H} 2$ & $\begin{array}{l}\mathrm{ND} \\
\mathrm{DD}\end{array}$ & $\begin{array}{l}82 \cdot 07 \pm 1 \cdot 94 \\
81 \cdot 55 \pm 1 \cdot 79\end{array}$ & $\begin{array}{l}79 \cdot 23 \pm 2 \cdot 24 \\
80 \cdot 21 \pm 2 \cdot 30\end{array}$ & $\begin{array}{l}72 \cdot 21 \pm 4 \cdot 60 \\
75 \cdot 63 \pm 4 \cdot 85\end{array}$ & $\begin{array}{l}2 \cdot 84 \\
1 \cdot 34\end{array}$ & $\begin{array}{l}\text { NS } \\
\text { NS }\end{array}$ & $\begin{array}{l}9 \cdot 86 \\
5 \cdot 92\end{array}$ & NS & $\begin{array}{l}7.02 \\
4.58\end{array}$ & $\begin{array}{l}\text { NS } \\
\text { NS }\end{array}$ \\
\hline LL & $\begin{array}{l}\mathrm{ND} \\
\mathrm{DD}\end{array}$ & $\begin{array}{l}47 \cdot 29 \pm 0 \cdot 34 \\
41 \cdot 11 \pm 0 \cdot 39\end{array}$ & $\begin{array}{l}45.35 \pm 0.65 \\
39.23 \pm 0.69\end{array}$ & $\begin{array}{l}50 \cdot 57 \pm 0 \cdot 84 \\
42 \cdot 32 \pm 1 \cdot 24\end{array}$ & $\begin{array}{l}1.94 \\
1.88\end{array}$ & $\begin{array}{l}\dagger \\
*\end{array}$ & $\begin{array}{l}-3 \cdot 28 \\
-1 \cdot 21\end{array}$ & $\begin{array}{l}\ddagger \\
\text { NS }\end{array}$ & $\begin{array}{l}-5 \cdot 22 \\
-3 \cdot 09\end{array}$ & $\underset{*}{\ddagger}$ \\
\hline LB & $\begin{array}{l}\text { ND } \\
\text { DD }\end{array}$ & $\begin{array}{l}25 \cdot 40 \pm 0 \cdot 28 \\
19 \cdot 32 \pm 0.25\end{array}$ & $\begin{array}{l}23 \cdot 61 \pm 0 \cdot 41 \\
18 \cdot 29 \pm 0 \cdot 38\end{array}$ & $\begin{array}{l}27.49 \pm 0.64 \\
20.58 \pm 0.65\end{array}$ & $\begin{array}{l}1.79 \\
1.03\end{array}$ & $\begin{array}{l}\dagger \\
+\end{array}$ & $\begin{array}{l}-2 \cdot 09 \\
-1 \cdot 26\end{array}$ & $\begin{array}{l}\ddagger \\
\text { NS }\end{array}$ & $\begin{array}{l}-3 \cdot 88 \\
-2 \cdot 29\end{array}$ & $\begin{array}{l}\ddagger \\
\ddagger\end{array}$ \\
\hline FT & $\begin{array}{l}\mathrm{ND} \\
\mathrm{DD}\end{array}$ & $\begin{array}{l}50 \cdot 38 \pm 1 \cdot 38 \\
71 \cdot 30 \pm 2 \cdot 02\end{array}$ & $\begin{array}{l}57 \cdot 00 \pm 1 \cdot 73 \\
76.97 \pm 2 \cdot 58\end{array}$ & $\begin{array}{l}56 \cdot 35 \pm 3 \cdot 81 \\
72 \cdot 00 \pm 5 \cdot 05\end{array}$ & $\begin{array}{l}-6 \cdot 62 \\
-5 \cdot 67\end{array}$ & $\stackrel{\dagger}{\mathrm{N} S}$ & $\begin{array}{l}-5.97 \\
-0.70\end{array}$ & $\begin{array}{l}\text { NS } \\
\text { NS }\end{array}$ & $\begin{array}{l}0.65 \\
4.97\end{array}$ & $\begin{array}{l}\text { NS } \\
\text { NS }\end{array}$ \\
\hline HFT & $\begin{array}{l}\mathrm{ND} \\
\mathrm{DD}\end{array}$ & $\begin{array}{l}151 \cdot 25 \pm 1.91 \\
132.83 \pm 1.99\end{array}$ & $\begin{array}{l}160 \cdot 62 \pm 2 \cdot 83 \\
142 \cdot 75 \pm 2 \cdot 50\end{array}$ & $\begin{array}{l}146 \cdot 27 \pm 3 \cdot 20 \\
109.28 \pm 5 \cdot 92\end{array}$ & $\begin{array}{l}-9 \cdot 37 \\
-9 \cdot 92\end{array}$ & $\begin{array}{l}\dagger \\
t\end{array}$ & $\begin{array}{r}4 \cdot 98 \\
23 \cdot 55\end{array}$ & $\begin{array}{l}\text { NS } \\
\ddagger\end{array}$ & $\begin{array}{l}14 \cdot 35 \\
33 \cdot 47\end{array}$ & $\begin{array}{l}\dagger \\
\ddagger\end{array}$ \\
\hline $\mathrm{FH}$ & $\begin{array}{l}\mathrm{ND} \\
\mathrm{DD}\end{array}$ & $\begin{array}{l}164 \cdot 61 \pm 1 \cdot 66 \\
144.39 \pm 1 \cdot 71\end{array}$ & $\begin{array}{l}169 \cdot 22 \pm 2 \cdot 91 \\
151 \cdot 47 \pm 2 \cdot 30\end{array}$ & $\begin{array}{l}161 \cdot 10 \pm 3 \cdot 21 \\
124 \cdot 55 \pm 5 \cdot 03\end{array}$ & $\begin{array}{l}-4 \cdot 61 \\
-7 \cdot 08\end{array}$ & $\begin{array}{l}\text { NS } \\
\dagger\end{array}$ & $\begin{array}{r}3 \cdot 50 \\
19 \cdot 84\end{array}$ & $\begin{array}{l}\text { NS } \\
\ddagger\end{array}$ & $\begin{array}{r}8 \cdot 12 \\
26 \cdot 92\end{array}$ & $\begin{array}{l}\text { NS } \\
\ddagger\end{array}$ \\
\hline TY & $\begin{array}{l}\mathrm{ND} \\
\mathrm{DD}\end{array}$ & $\begin{array}{l}28.74 \pm 0.51 \\
15.65 \pm 0.39\end{array}$ & $\begin{array}{l}29.44 \pm 0.87 \\
16.42 \pm 0.60\end{array}$ & $\begin{array}{l}30 \cdot 26 \pm 1 \cdot 53 \\
15 \cdot 27 \pm 1 \cdot 25\end{array}$ & $\begin{array}{l}-0.70 \\
-0.77\end{array}$ & $\begin{array}{l}\text { NS } \\
\text { NS }\end{array}$ & $\begin{array}{r}-1.52 \\
0.38\end{array}$ & $\begin{array}{l}\text { NS } \\
\text { NS }\end{array}$ & $\begin{array}{r}-0.82 \\
1.15\end{array}$ & $\begin{array}{l}\text { NS } \\
\text { NS }\end{array}$ \\
\hline LN & $\begin{array}{l}\mathrm{ND} \\
\mathrm{DD}\end{array}$ & $\begin{array}{l}19 \cdot 27 \pm 0.25 \\
19.96 \pm 0.24\end{array}$ & $\begin{array}{l}21 \cdot 21 \pm 0 \cdot 44 \\
21 \cdot 22 \pm 0 \cdot 38\end{array}$ & $\begin{array}{l}19 \cdot 67 \pm 0.63 \\
17 \cdot 21 \pm 0 \cdot 72\end{array}$ & $\begin{array}{l}-1.94 \\
-1.26\end{array}$ & $\begin{array}{l}\ddagger \\
\dagger\end{array}$ & $\begin{array}{r}-0.40 \\
2.75\end{array}$ & $\begin{array}{l}\text { NS } \\
\ddagger\end{array}$ & $\begin{array}{l}1 \cdot 54 \\
4 \cdot 01\end{array}$ & $\begin{array}{l}* \\
\ddagger\end{array}$ \\
\hline SY & $\begin{array}{l}\mathrm{ND} \\
\mathrm{DD}\end{array}$ & $\begin{array}{l}18.62 \pm 0.34 \\
10 \cdot 18 \pm 0.25\end{array}$ & $\begin{array}{l}19 \cdot 65 \pm 0.58 \\
11 \cdot 10 \pm 0.42\end{array}$ & $\begin{array}{r}19.34 \pm 0.97 \\
9.86 \pm 0.80\end{array}$ & $\begin{array}{l}-1.03 \\
-0.92\end{array}$ & $\begin{array}{l}\text { NS } \\
\text { NS }\end{array}$ & $\begin{array}{r}-0.72 \\
0.32\end{array}$ & $\begin{array}{l}\text { NS } \\
\text { NS }\end{array}$ & $\begin{array}{l}0.31 \\
1.24\end{array}$ & $\begin{array}{l}\text { NS } \\
\text { NS }\end{array}$ \\
\hline LY & $\begin{array}{l}\mathrm{ND} \\
\mathrm{DD}\end{array}$ & $\begin{array}{r}10 \cdot 13 \pm 0 \cdot 22 \\
7 \cdot 47 \pm 0 \cdot 10\end{array}$ & $\begin{array}{l}9.79 \pm 0.34 \\
7.37 \pm 0.12\end{array}$ & $\begin{array}{r}10.92 \pm 0.71 \\
9.86 \pm 0.80\end{array}$ & $\begin{array}{l}0 \cdot 34 \\
0 \cdot 10\end{array}$ & $\begin{array}{l}\text { NS } \\
\text { NS }\end{array}$ & $\begin{array}{l}-0.79 \\
-2 \cdot 39\end{array}$ & $\begin{array}{l}\text { NS } \\
\ddagger\end{array}$ & $\begin{array}{l}-1 \cdot 13 \\
-2 \cdot 49\end{array}$ & $\begin{array}{l}\text { NS } \\
\ddagger\end{array}$ \\
\hline
\end{tabular}

NS $P>0.05$

* $P=0.05-0.01$

$+\mathrm{P}=0.01-0.001$

$\ddagger \mathrm{P}<0 \cdot 0001$ 
that the inbred lines are completely homozygous (see Materials and Methods) we can estimate the additive genetic $\mathrm{D}$, and additive environmental $\mathrm{E}$, components of variation as the between and within family components of variance, respectively. We can further test whether these estimates of D and $E$ are the same for the SSD and DH samples of inbred lines using the maximum likelihood procedure described by Pooni, Jinks and Pooni (1980). The results of this test (table 3 ) show that a model which assumes that the D's are the same for both samples is satisfactory for all character density combinations except $\mathrm{H} 1$ and LL in both densities. For $\mathrm{H} 1$ the SSD sample has a significantly larger $\mathrm{D}$ while for LL it has a significantly smaller D.

There are nine character-density combinations out of 22 where a model which assumed that the E's are the same in the SSD and DH samples of inbred lines has failed (table 3). For seven of these, the two exceptions being FT at the normal density and $\mathrm{LN}$ at the double density, the E for the SSD sample is the larger. Since the SSD sample is not expected to be completely homozygous like the DH sample, being a mixture of $F_{6}, F_{7}$ and $F_{8}$ families, the larger $E$ probably arises from the genetic segregation within families resulting from the residual heterozygosity.
The parental, $F_{1}, F_{2}$ and first backcross families were subjected to the standard biometrical genetical analyses to determine the genetical components of the means and variances (Mather and Jinks, 1982). The only results of these analyses that are of direct relevance are those components which could contribute to the differences in the properties of the SSD and DH samples of inbred lines and the deviations of their means from the mid-parental value $(\mathrm{mp})$. These are referred to in the next section and summarised in table 4.

\section{INTERPRETATION AND CONCLUSIONS}

There are differences between the means of the SSD and DH samples of inbred lines for ten of the 22 character-density combinations and for six of these the DH mean is the larger (table 2 and Results). A number of explanations have been put forward by other workers for the comparable differences that they have found. For example:

(i) Greater inbreeding depression in the dihaploids because they lack the residual heterozygosity present in conventionally produced inbred lines.

Table 3 Weighted least square estimates of the additive genetic (D) and additive environmental (E) components of variation for the combined SSI and DH samples of inbred lines

\begin{tabular}{|c|c|c|c|c|c|c|c|c|c|}
\hline Character & Density & $\mathrm{D}_{\mathrm{SSD}}$ & $\mathrm{D}_{\mathrm{DH}}$ & Joint D & $E_{\mathrm{SSIS}}$ & $\mathrm{E}_{\mathrm{DH}}$ & Joint $E$ & $\mathrm{df}$ & $\chi^{2 *}$ \\
\hline $\mathrm{H} 1$ & $\begin{array}{l}\text { ND } \\
\text { DD }\end{array}$ & $\begin{array}{r}25 \cdot 8 \\
105 \cdot 4\end{array}$ & $\begin{array}{r}8 \cdot 9 \\
48 \cdot 1\end{array}$ & - & $\begin{array}{r}44 \cdot 4 \\
234 \cdot 7\end{array}$ & $\begin{array}{r}35.4 \\
173 \cdot 5\end{array}$ & - & - & - \\
\hline $\mathrm{H} 2$ & $\begin{array}{l}\text { ND } \\
\text { DD }\end{array}$ & - & - & $\begin{array}{l}325 \cdot 8 \\
281 \cdot 3\end{array}$ & $\begin{array}{l}837 \cdot 0 \\
-\end{array}$ & $\begin{array}{l}684 \cdot 0 \\
-\end{array}$ & $\overline{822 \cdot 2}$ & $\begin{array}{l}1 \\
2\end{array}$ & $\begin{array}{l}2.89 \\
5.92\end{array}$ \\
\hline LL & $\begin{array}{l}\text { ND } \\
\text { DI) }\end{array}$ & $\begin{array}{l}10 \cdot 3 \\
13 \cdot 4\end{array}$ & $\begin{array}{l}21 \cdot 3 \\
22 \cdot 4\end{array}$ & - & - & - & $\begin{array}{l}36 \cdot 2 \\
47 \cdot 5\end{array}$ & $\begin{array}{l}1 \\
1\end{array}$ & $\begin{array}{l}0.22 \\
1.92\end{array}$ \\
\hline LB & $\begin{array}{l}\text { ND } \\
\text { DD }\end{array}$ & - & - & $\begin{array}{l}8 \cdot 1 \\
6 \cdot 1\end{array}$ & - & $\overline{12} \cdot 8$ & $-^{18.6}$ & $\begin{array}{l}2 \\
1\end{array}$ & $\begin{array}{l}1 \cdot 10 \\
0.44\end{array}$ \\
\hline FT & $\begin{array}{l}\text { ND } \\
\text { DD }\end{array}$ & - & - & $\begin{array}{l}189 \cdot 4 \\
397 \cdot 1\end{array}$ & $\begin{array}{l}255 \cdot 7 \\
693 \cdot 2\end{array}$ & $\begin{array}{l}325.5 \\
528.7\end{array}$ & - & $\begin{array}{l}1 \\
1\end{array}$ & $\begin{array}{l}1 \cdot 80 \\
1 \cdot 11\end{array}$ \\
\hline HFT & $\begin{array}{l}\text { ND } \\
\text { DD }\end{array}$ & - & - & $\begin{array}{l}420 \cdot 7 \\
339 \cdot 0\end{array}$ & $\begin{array}{l}461 \cdot 0 \\
-\end{array}$ & $\begin{array}{l}280 \cdot 2 \\
-\end{array}$ & $-\overline{10} 14 \cdot 8$ & $\begin{array}{l}1 \\
2\end{array}$ & $\begin{array}{l}0 \cdot 16 \\
4 \cdot 04\end{array}$ \\
\hline $\mathrm{FH}$ & $\begin{array}{l}\text { NI) } \\
\text { DD }\end{array}$ & - & - & $\begin{array}{l}359 \cdot 7 \\
251 \cdot 6\end{array}$ & $\begin{array}{l}363 \cdot 7 \\
-\end{array}$ & $302 \cdot 5$ & $\overline{-}_{844.0}$ & $\begin{array}{l}1 \\
2\end{array}$ & $\begin{array}{l}3 \cdot 66 \\
1.93\end{array}$ \\
\hline TY & $\begin{array}{l}\text { ND } \\
\text { DD }\end{array}$ & - & - & $\begin{array}{l}27 \cdot 0 \\
14 \cdot 4\end{array}$ & - & - & $\begin{array}{l}89 \cdot 2 \\
44 \cdot 1\end{array}$ & $\begin{array}{l}2 \\
2\end{array}$ & $\begin{array}{l}2 \cdot 28 \\
2 \cdot 84\end{array}$ \\
\hline LN & $\begin{array}{l}\text { ND } \\
\text { DD }\end{array}$ & - & - & $\begin{array}{l}7 \cdot 3 \\
5 \cdot 8\end{array}$ & $-_{14.7}$ & $-_{18 \cdot 5}$ & $-^{10.9}$ & $\begin{array}{l}2 \\
1\end{array}$ & $\begin{array}{l}0.99 \\
0.06\end{array}$ \\
\hline SY & $\begin{array}{l}\text { ND } \\
\text { DD }\end{array}$ & - & - & $\begin{array}{r}11 \cdot 1 \\
5 \cdot 7\end{array}$ & - & - & $\begin{array}{l}46 \cdot 7 \\
25 \cdot 0\end{array}$ & $\begin{array}{l}2 \\
2\end{array}$ & $\begin{array}{l}3 \cdot 50 \\
4 \cdot 40\end{array}$ \\
\hline LY & $\begin{array}{l}\text { ND } \\
\text { DD }\end{array}$ & - & - & $\begin{array}{l}4 \cdot 8 \\
2 \cdot 5\end{array}$ & - & - & $\begin{array}{r}12 \cdot 4 \\
5 \cdot 4\end{array}$ & $\begin{array}{l}2 \\
2\end{array}$ & $\begin{array}{l}1 \cdot 46 \\
3 \cdot 42\end{array}$ \\
\hline
\end{tabular}


Table 4 The observed rank orders of the mid-parental value ( $\mathrm{mp}$ ) and the means of the SSD and DH samples of inbred lines for each of the 11 characters $\times 2$ density combinations, the categorisation of the rank orders and the results of tests for the presence of non-allelic interaction, a linkage disequilibrium of interacting genes and higher order interactions

\begin{tabular}{|c|c|c|c|c|c|c|c|}
\hline \multirow[b]{2}{*}{ Character } & \multirow[b]{2}{*}{ Density } & \multicolumn{4}{|c|}{ Observed ranking* } & \multirow{2}{*}{$\begin{array}{l}\text { Non-allelic } \\
\text { interaction }\end{array}$} & \multirow{2}{*}{$\begin{array}{l}\text { Linkage } \\
\text { disequilibrium } \\
\text { or higher } \\
\text { order } \\
\text { interactions }\end{array}$} \\
\hline & & 1 & 2 & 3 & Category & & \\
\hline $\mathrm{H} 1$ & $\begin{array}{l}\text { ND } \\
\text { DD }\end{array}$ & $\begin{array}{l}\mathrm{DH}= \\
\mathrm{SSD}=\end{array}$ & $\begin{array}{l}\mathrm{SSD} \gg \\
\mathrm{mp}=\end{array}$ & $\begin{array}{l}\mathrm{mp} \\
\mathrm{DH}\end{array}$ & $\begin{array}{l}2 \\
1\end{array}$ & - & \\
\hline $\mathrm{H} 2$ & $\begin{array}{l}\text { ND } \\
\text { DD }\end{array}$ & $\begin{array}{l}\mathrm{SSD}= \\
\mathrm{SSD}=\end{array}$ & $\begin{array}{l}\mathrm{DH} \geqq \\
\mathrm{DH}=\end{array}$ & $\begin{array}{l}\mathrm{mp} \\
\mathrm{mp}\end{array}$ & $\begin{array}{l}2 \\
1\end{array}$ & & \\
\hline LL & $\begin{array}{l}\text { ND } \\
\text { DD }\end{array}$ & $\begin{array}{l}m p » \gg \\
m p »\end{array}$ & $\begin{array}{l}S D \gg \\
S S D>\end{array}$ & $\begin{array}{l}\mathrm{DH} \\
\mathrm{DH}\end{array}$ & $\begin{array}{l}5 \\
4 / 5\end{array}$ & + & $\ddagger$ \\
\hline LB & $\begin{array}{l}\text { ND } \\
\text { DD }\end{array}$ & $\begin{array}{l}m p » \gg \\
m p \geqslant\end{array}$ & $\begin{array}{l}S S D \gg \\
S S D>\end{array}$ & $\begin{array}{l}\text { DH } \\
\text { DH }\end{array}$ & $\begin{array}{l}5 \\
4 / 5\end{array}$ & + & $\ddagger$ \\
\hline FT & $\begin{array}{l}\mathrm{ND} \\
\mathrm{DD}\end{array}$ & $\begin{array}{l}\mathrm{DH}= \\
\mathrm{DH}=\end{array}$ & $\begin{array}{l}\mathrm{mp} \geqq \\
\mathrm{mp}=\end{array}$ & $\begin{array}{l}\text { SSD } \\
\text { SSD }\end{array}$ & $\begin{array}{l}3 / 4 \\
1\end{array}$ & - & $\ddagger$ \\
\hline HFT & $\begin{array}{l}\text { ND } \\
\text { DD }\end{array}$ & $\begin{array}{l}\mathrm{DH} \gg \\
\mathrm{DH} \gg\end{array}$ & $\begin{array}{l}S S D \geqq \\
S S D \gg\end{array}$ & $\begin{array}{l}\mathrm{mp} \\
\mathrm{mp}\end{array}$ & $\begin{array}{l}4 / 5 \\
5\end{array}$ & & $\begin{array}{l}\ddagger \\
\ddagger\end{array}$ \\
\hline FH & $\begin{array}{l}\text { ND } \\
\text { DD }\end{array}$ & $\begin{array}{l}\mathrm{DH}= \\
\mathrm{DH}>\end{array}$ & $\begin{array}{l}\mathrm{SSD}= \\
\mathrm{SSD} \gg\end{array}$ & $\begin{array}{l}\mathrm{mp} \\
\mathrm{mp}\end{array}$ & $\begin{array}{l}1 \\
5\end{array}$ & + & \\
\hline TY & $\begin{array}{l}\text { ND } \\
\text { DD }\end{array}$ & $\begin{array}{l}\mathrm{mp}= \\
\mathrm{DH}=\end{array}$ & $\begin{array}{l}\mathrm{DH}= \\
\mathrm{SSD}=\end{array}$ & $\begin{array}{l}\text { SSD } \\
\mathrm{mp}\end{array}$ & $\begin{array}{l}1 \\
1\end{array}$ & + & \\
\hline LN & $\begin{array}{l}\text { ND } \\
\text { DD }\end{array}$ & $\begin{array}{l}\mathrm{DH} \gg \\
\mathrm{DH} \gg\end{array}$ & $\begin{array}{l}\mathrm{mp}= \\
\mathrm{SSD} \gg\end{array}$ & $\begin{array}{l}\text { SSD } \\
\mathrm{mp}\end{array}$ & $\begin{array}{l}4 / 5 \\
5\end{array}$ & & $\ddagger$ \\
\hline SY & $\begin{array}{l}\text { ND } \\
\text { DD }\end{array}$ & $\begin{array}{l}\mathrm{DH}= \\
\mathrm{DH}=\end{array}$ & $\begin{array}{l}\mathrm{mp}= \\
\mathrm{SSD}=\end{array}$ & $\begin{array}{l}\text { SSD } \\
\mathrm{mp}\end{array}$ & $\begin{array}{l}1 \\
1\end{array}$ & + & \\
\hline LY & $\begin{array}{l}\text { ND } \\
\text { DD }\end{array}$ & $\begin{array}{l}\mathrm{mp}= \\
\mathrm{mp} \gg \gg\end{array}$ & $\begin{array}{l}\mathrm{SSD}= \\
\mathrm{SSD}=\end{array}$ & $\begin{array}{l}\text { DH } \\
\text { DH }\end{array}$ & $\begin{array}{l}1 \\
3 / 4\end{array}$ & + & \\
\hline
\end{tabular}

$*$ difference not significant $(\mathbf{P}>0.05)$

$\geqq$ not significantly different from the next in rank but significantly different from the next but one

$>$ difference significant at $\mathbf{P}=0.05-0.01$

$\gg$ difference significant at $\mathbf{P}=0.01-0.001$

》difference significant at $\mathbf{P}<0.01$

+ or - significant positive or negative estimate of $[i]$, the additive $\times$ additive non-allelic interaction component of means.

$\ddagger$ Significant failure of the digenic non-allelic interaction model due to a linkage disequilibrium of interacting genes or to higher order interaction.

(ii) Random or systematic mutation during anther culture.

(iii) Mutagenic effects of colchicine induced chromosome doubling of haploids.

(iv) A cytoplasmic deficiency due to the unconventional source of the cytoplasm in dihap. loids obtained from anther culture.

(v) Preferential selection among microspores during anther culture.

(vi) Poor seed quality in the first generation dihaploids as a consequence of the colchicine treatment.

With the possible exception of $(\mathrm{v})$ all these explanations lead to the expectation that the $\mathrm{DH}$ sample would be the less vigorous of the two. This is clearly not the case and any adequate explanation must account for the $\mathrm{DH}$ mean being the larger for some characters, the smaller for others and the same for the remainder. The alternative explanations of Jinks and Pooni (1981) based upon the nature of the genetical control of each character would, therefore, appear to be more appropriate.

These in summary are as follows:

1. With a linkage equilibrium and a positive value for $[i]=r_{i} \sum^{\frac{1}{2} k(k-1)} i$, the additive $\mathrm{x}$ additive epistatic component of means as estimated from the parental, $F_{1}, F_{2}, B_{1}$ and $B_{2}$ family means, the rank order of the three means is $m p>\overline{\mathrm{DH}}=\overline{\mathrm{SSD}}$. With a negative value for $[i]$ this becomes $\overline{\mathrm{DH}}=\overline{\mathrm{SSD}}>$ mp.

2. With a linkage disequilibrium arising from an excess of coupling linkages between pairs of loci with positive $i$ 's or of repulsion linkages between pairs of loci with negative $i$ 's the DH and SSD 
means are no longer equal, the rank order being $\overline{\mathrm{DH}}>\overline{\mathrm{SSD}}$. With an excess of repulsion linkages between pairs of loci with positive $i$ 's or of coupling linkages between pairs of loci with negative $i$ 's the rank order is reversed to become $\overline{\mathrm{SSD}}<\overline{\mathrm{DH}}$.

3. In the presence of a linkage disequilibrium the ranking of $\mathrm{mp}$ relative to the means of SSD and DH depends on the proportion of the pairs of interacting loci which are also linked. To illustrate this we must divide the $\frac{1}{2} k(k-1)$ pairs of loci in respect of $k$ loci at which the two parental varieties differ into three groups; those which show epistasis and linkage $\left(k_{1}\right)$; those which show epistasis and no linkage $\left(k_{2}\right)$, and those which show no epistasis $\left(k_{3}\right)$. Whereupon following Jinks and Pooni (1981) the

$$
\begin{aligned}
& \mathrm{mp}=m+r_{i}\left(\sum^{k_{1}} i+\sum^{k_{2}} i\right) \\
& \overline{\mathrm{DH}}=m+\sum^{k_{!}}(1-2 p) i
\end{aligned}
$$

and

$$
\overline{\mathrm{SSD}}=m+\sum^{k_{1}}\left[(1-2 p) i-\frac{2 p(1-2 p)}{1+2 p} i\right]
$$

If $k_{2}$ is zero, that is all interacting pairs of genes are linked, only two rankings are possible among the three means $\mathrm{mp}>\overline{\mathrm{DH}}>\overline{\mathrm{SSD}}$ and $\overline{\mathrm{SSD}}>\overline{\mathrm{DH}}>$ $\mathrm{mp}$ that is the DH mean must always be intermediate. If, however, $k_{2}$ is not zero either $\mathrm{mp}$ or SSD may be intermediate, that is, $\overline{\mathrm{DH}}>\mathrm{mp}>\overline{\mathrm{SSD}}$ and $\overline{\mathrm{SSD}}>\mathrm{mp}>\overline{\mathrm{DH}}$ or, $\overline{\mathrm{DH}}>\overline{\mathrm{SSD}}>\mathrm{mp}$ and $\mathrm{mp}>$ $\overline{\mathrm{SSD}}>\overline{\mathrm{DH}}$, depending upon whether the contribution of the unlinked interacting genes are of the same order or much greater than those of the linked interacting genes and whether the two contributions are of the same or of opposite sign.

The observed rank orders of the mid-parental values $(\mathrm{mp})$ and the means of the SSD and DH samples of inbred lines are given in table 4 for each of the 22 character-density combinations. For nine of these combinations (category 1 table 4), which include seven of the 11 characters in one or both densities, the three means do not differ significantly as expected on the simpler genetical models. For these combinations, which exclude only three leaf characters (LL, LB and LN) and one height measurement (HFT); we have, therefore, no reason to believe that there has been a failure of any of the assumptions underlying a simple genetical model and we can rule out all the special explanations put forward to account for the reduced vigour of dihaploids.

In two further combinations (category 2 in table 4) the only inequality between the three means is that $\mathrm{mp}$ is significantly smaller than one or both of the SSD or DH sample means. For H1, where $\mathrm{mp}$ is significantly smaller than both means $(\mathrm{P}=$ $0.01-0.001)$, this is as expected since the $[i]$ component of the generation means estimated from the basic generations (parental, $F_{1}, F_{2}, B_{1}$ and $B_{2}$ families) is significant and negative (table 4). For $\mathrm{H} 2$, where $\mathrm{mp}$ is not significantly different from the DH mean and just significantly different from the SSD mean $(P=0 \cdot 05)$ there is no significant $[i]$ component.

For the remaining ten combinations the means of the two samples of inbred lines differ significantly in addition to one or both of them differing significantly from the $\mathrm{mp}$ value (categories 3 , 4 and 5 in table 4 ). For 4 of these combinations, leaf length (LL) and breadth (LB) in both densities these differences are associated with the DH sample having the lowest mean. In the remaining six combinations the DH mean is the highest of the three means. The significant differences between these three means are not, therefore, simply a consequence of reduced vigour in the $\mathrm{DH}$ sample.

As we have seen the only genetical explanations for the significant differences between the three means is a linkage disequilibrium at loci displaying non-allelic interactions. In the present data we have no unambiguous test for such effects. By using all the available generation means including those of the basic generations and of the SSD and DH samples of inbred lines we can, however, test the adequacy of the six component digenic interaction model the only genetical causes of inadequacy being either a linkage disequilibrium of interacting genes or trigenic and higher order interactions (Jinks and Perkins, 1969; Jinks, 1978). This model fails for six of the ten combinations, namely, LL, LB, FT, HFT and LN at the normal density (ND) and HFT at the double density (DD). These are six of the seven combinations where the difference in the means of the SSD and DH samples is significant at $\mathrm{P}<0.01$ (table + ).

It could, of course, be argued that the failure of the model in the six combinations arises solely from the highly significant difference between the means of the SSD and DH samples and hence it is not independent evidence for the presence of a linkage disequilibrium of interacting genes or higher order interactions. This explanation is, however, made much less likely by the failure of the digenic interaction model even when we reduce the sensitivities of the tests by including only one of the two means in the analysis, which is the case for three of the six combinations (LL, LB and HFT at the normal density). 
Because the test for the inadequacy of a digenic interaction model is less sensitive than that for the differences between the three means ( $\mathrm{mp}$, SSD and $\mathrm{DH}$ ) and the two causes of failure, trigenic interaction and a linkage dis-equilibrium of interacting genes are confounded, we cannot obtain clearer evidence of the cause of the inequality of the three means using the present data. We can however divide the cases of inequality into three categories (3, 4 and 5 in table 4) corresponding with the theoretical expectations given earlier, namely the DH mean intermediate (category 3 ), the mp value intermediate (category 4) and the SSD mean intermediate (category 5). There are no unambiguous examples of categories 3 and 4 and category 5 is by far the most common. This is the category in which there must be a substantial proportion of the interacting genes which are unlinked and the contribution that they make to the mean must be opposite in sign to that made by those that are linked. This could arise because the linked and unlinked interacting genes are displaying different types of interaction, for example, complementary and duplicate or because they are distributed in different phases in the parental lines, for example, association and dispersion.

Only two of the 11 characters show any evidence that the genotypic distribution around the mean differs significantly between the SSD and DH samples of inbred lines (table 3 ). For one of these characters $\mathrm{H} 1$ there is no evidence that the means differ (tables 2 and 4). Either, therefore, the difference $\left(D_{\mathrm{SSD}}>D_{\mathrm{DH}}\right)$ is due to sampling error or there is an excess of repulsion linkages involving non-interacting genes only (Mather and Jinks, 1982). For the other character LL, the means differ significantly and from the model fitting to the means there is evidence of positive non-allelic interactions and of a linkage disequilibrium involving interacting genes (table 4). Since $D_{\mathrm{SSD}}<D_{\mathrm{DH}}$ the predominant phase must be coupling.

In conclusion, therefore, our analyses show that for many characters there are no significant differences in mean and variance between SSD and DH samples of inbred lines and for most characters there is no suggestion that the $\mathrm{DH}$ sample is showing reduced vigour. It is quite clear that the relationship between the properties of the SSD and DH samples of inbred lines is character specific and can be related to the genetical control of the character as revealed by independent genetical analysis. Where there is a significant difference between the means of the SSD and DH samples of inbred lines and between these and the midparent value we expect to find non-allelic interac- tions and a linkage disequilibrium of interacting genes and within the limitations of the data we have found both.

\section{REFERENCES}

ARCiA, M. A., Wensman, E. A. AND BURK, L. G. 1978. Performance of anther-derived dihaploids and their conventionally inbred parents as lines, in $F_{1}$ hybrids and $F_{2}$ generations. Crop Sci., 18, 413-418.

BROWN, J. S. ANI WENSMAN, E. A. 1982. Nature of reduced productivity of anther-derived dihaploid lines of flue-cured tobacco. Crop Sci., 22, 1-5.

BROWN, J. S., WERNSMAN, E. A. AND SCHNELL, R. J. 1983. Effect of a second cycle of anther culture on flue-cured lines of tobacco. Crop Sci., 23, 729-733.

BURK, L. G., GWYNN, G. R. AND CHAPLIN, J. F. 1972. Diploidized haploids from aseptically cultured anthers of Nicotiana rustica. J. Hered., 63, 355-360.

BURK, L. G. AND MATZINGER, D. F. 1976. Variation among anther derived doubled haploids from an inbred line of tobacco. J. Hered., 67, 381-384.

COLLINS, G. B., LEGG, P. D. AND LITTON, C ( . 1973. The use of anther derived haploids in Nicotiana II. Comparison of doubled haploid lines with lines obtained by conventional breeding methods. Tob. Sci., 18, 40-42.

COOMBS, D. 1980. Biometrical genetics of tobacco. Ph.D. Thesis, Department of Genetics, University of Birmingham.

DENTON, W. R., LEGG, P. D. AND COLLINS, G. B. 1982. A comparison of burley tobacco doubled haploid lines with their source inbred cultivars. Theor. Appl. Genet., 62, 69-74.

GUHA, S. AND MAHESHWARI, S. C. 1964. In vitro production of embryos from anthers of Datura. Nature, 204, 497.

GUhA, S. AND MAHESHWARI, S. C. 1966. Cell division and differentiation of embryos in the pollen grains of Datura in vitro. Nature, 212, 97-98.

JINKS, J. L. 1978. Unambiguous test for linkage of genes displaying non-allelic interactions for a metrical trait. Heredity, $40,171-173$.

JINKS, J. L. AND PERKINS, J. M. 1969. The detection of linked epistatic genes for a metrical trait. Heredity, 24, 465-475.

JINKS, J. L. ANI POONI, H. S. 1981. Properties of pure breeding lines produced by dihaploidy, single seed descent and pedigree inbreeding. Heredity, 46, 391-395.

KASPERBAUER, M. J., LEGG, P. D. AND SUTTON, T. G. 1983. Growth development and alkaloid contact of doubled haploids vs. inbreds of burley tobacco. Crop Sci., 23, 965969.

MATHER, K. AND JINKS, J. L. 1982. Biometrical Genetics 3rd edn. Chapman and Hall, London.

OINUMA, T. AND YOSHIDA, T. 1974. Genetic variation among doubled haploid lines of burley tobacco varieties. Jap. $J$. Breed., 24, 211-216.

POONI, H. S., JINKS, J. L. AND POONI, G. S. 1980. A general method for detection and estimation of additive, dominance and epistatic variation for metrical traits IV. Triple test cross analysis for normal families and their selfs. Heredity, 44, 177-182.

SCHNELL, R. J., WENSMAN, E. A. AND BURK, L. G. 1980. Efficiency of single seed descent vs. anther derived breeding methods. Crop Sci., 20, 619-622. 